\title{
My experience as a Quarantine Officer welcoming Syrian refugees
}

\author{
$\mathrm{D}^{\prime}$ Amour $\mathrm{R}^{1 *}$
}

\author{
Affiliation \\ ${ }^{1}$ Infectious Disease Prevention and Control Branch, Public Health Agency of Canada, Ottawa, ON \\ *Correspondence: rolande.damour@phac-aspc.gc.ca
}

Suggested citation: D'Amour R. My experience as a Quarantine Officer welcoming Syrian refugees. Can Comm Dis Rep 2016;42-Suppl 2:S11-2. https://doi.org/10.14745/ccdr.v42is2a04

\begin{abstract}
I have been a nurse with the Public Health Agency of Canada for nearly 15 years. Last fall, I received an email requesting volunteers to support and assist quarantine officers during the arrival of Syrian refugees at the Montréal and Toronto airports. I asked myself, "Why not get out of my cubicle and my comfort zone and submit my name to help?" I sent in my application and soon after participated in quarantine officer training offered by the Agency's Office of Border Health Services - Quarantine. During the training sessions, quarantine officers from various parts of the country presented the basics of training (such as our obligations under the Quarantine Act) which we had to learn and apply. Our days were filled with case simulations in small groups, where we discussed the procedure to follow for different scenarios. We practiced wearing personal protective equipment and were fit tested for the $\mathrm{N}-95$ respirator. I then returned to my regular job and waited to hear whether I would be needed and if so, when and at which airport.
\end{abstract}

Weeks passed and like everyone, I began to hear news reports about the Canadian arrival of the first Syrian refugees. I thought about all the organization that was required at all levels and I could not even imagine all the coordination and collaboration involved. Then on Wednesday, December 30, I received the much-anticipated email asking me to come to Pierre Elliott Trudeau International Airport in Montréal the following Tuesday. I had been chosen! I felt excited and frightened at the same time. Was I up to it? I would need to reread my training notes!

I have been to a number of airports to fly to different destinations around the world. During those times, I was so preoccupied with ensuring I had my ticket and travel documents handy, I never really considered what was going on behind the scenes at the airport. Well, I was soon to find out that there is a whole team of people working diligently to prevent the introduction of communicable diseases into Canada. The team includes quarantine officers. I was on the team for 15 days.

Before the flights arrived, we met in the quarantine office for an information session regarding the details of the flight. Sometimes, the quarantine officers had basic information, such as the number of passengers or the presence of medical conditions that needed to be reported to the paramedics and to Immigration, Refugees and Citizenship Canada (IRCC). The quarantine officers were particularly concerned with passengers who were suspected of having a communicable disease. Those passengers would need to be seen and assessed and, if indicated, a report would be sent to local public health for follow-up.

After the pre-flight information session, we went to Gate 19, a large area dedicated to welcoming refugees. The first time I went in, I was impressed by the number of people there. Myself and IRCC colleagues were designated by a fluorescent yellow vest. Volunteers wore red vests and interpreters wore blue vests. Customs officers, dressed in black, were in a section with over 20 desks and computers, biometric equipment and other security devices. First responders also had a section. Security officers ensured that only authorized individuals entered the area.

A few minutes before the flight arrived, we were waiting with our team. The aisles were empty and we were whispering. We checked our quarantine officer kits to make sure that everything was in its place, that our tympanic thermometers were working and that we had enough quarantine report questionnaires and paper for note taking. When nearly 300 passengers of all ages came through the doors, we would have to act quickly and work efficiently!

That is when I most felt the nervousness and excitement. And it was not just me: The interpreters, volunteers and my colleagues from IRCC felt it too. Something big was about to happen. A customs officer came to get us and asked two quarantine officers to get into the Passenger Transfer Vehicle (PTV), a large bus with a mechanism that allowed it to be raised to the doors of large airplanes. Then we waited for the plane to land.

Once the plane landed, the PTV approached, docked and we boarded the plane where the chief customs officer was already carrying out security procedures with his/her team. Mr. Joseph, the interpreter (who did not miss a single flight), made an announcement to welcome the passengers and asked them to remain seated while we worked. Our job was to check whether there were sick individuals on board and decide with the paramedic and the team whether the patient needed a wheelchair and should be examined.

I was surprised the first time I got out of the PTV and entered the plane. There was so much noise! I could hear the motor of the PTV, announcements on the microphone, discussions between the customs officers and the team, the hiss of the small ceiling vents and the passengers talking. We had to concentrate very hard when we met with medical escorts on board so they 
I witnessed small acts of kindness from the customs officers, who at first looked intimidating, dressed all in black with bulletproof vests. Although they looked serious and were focused on their work, they still took the time to be kind to the families. All of the teams noticed this and remarked on their efficiency.

After speaking with medical staff from the International Organization for Migration (IOM) who accompanied the refugees on the flight, we announced that people in the first rows could disembark from the plane and enter the PTV. The quarantine officers were the first to see each passenger disembark from the plane. We watched for any sign of a communicable disease, such as a cough, a rash or fever. If a sign was present, we met with the person to take his/her temperature and asked questions through an interpreter to assess whether or not they had a communicable disease. The passengers then got into the PTV with their families and their carry-on bags.

I must say the first trip in the PTV made me emotional, because I was meeting people who had left their country and their lives, to come to a new and strange country. Our eyes met and they spoke volumes without words. I said hello and welcomed them with my voice, and my eyes certainly conveyed the same message. They responded with a tired but relieved expression. A smile is contagious. It is a universal language. Everyone was calm, even the children.

We shifted into work mode and each of the customs officers, interpreters, volunteers, quarantine officers, security officers and first responders began to carry out their specific jobs and work together to complete the various steps of the arrival process.

The large families surprised me at first, bringing back memories of my childhood when families were larger than today. Syrian children are like any children: They smile when someone smiles at them. They waved back when we waved to them. On each flight, there was always a little clown, an outgoing child who would wave to us animatedly and give us a huge smile full of hope and gratitude. We noticed that the older children took care of their younger brothers and sisters when the parents would leave their chairs to meet with the customs officers, sometimes for a long time. The customs process takes time and everyone remained seated and calm. There was a lot of activity and the families remained close together moving from station to station for checks.

My days working there were very busy and I did not have much time to chat with my colleagues. However, I did have an opportunity to talk with a few volunteers who were allowed to assist us. Like me, they remarked on the cooperation among the teams and were touched by the humanity of what we called "Operation Hope". We all enjoyed our experience.

The people I spoke with most often were our precious interpreters in the blue vests, who made it possible for us to communicate with sick passengers to explain that we were going to take their temperature, ask them questions and assess their signs and symptoms. Every detail was important and we had to be brief and clear because the passengers had experienced a long trip and there were still a few more hours to go before they arrived at the Welcome Centre where they would receive winter clothes, their health card and be seen at the clinic if necessary. At the Welcome Centre, the refugees would also meet their host family or be transferred to another Canadian city.
I also noticed that, very often, the refugees spoke a few words of French or English. I knew only one word in Arabic: "Shukran," which means thank you. One time, after examining a child with a cold, I was informed by an interpreter that next was a child showing symptoms of a fever. After finishing my exam, with the help of the interpreter, I told the child's mother that the child did not have a fever and had no other symptoms. We encouraged her to remove the child's heavy coat and tuque while waiting for the bus that would take them to the Welcome Centre. Before leaving, she said something I did not understand. I responded with "Shukran," and she gave me a big smile and said "Thank you."

My training as a nurse and my work at the Agency allowed me to be a part of this historic event. I played my part in the Syrian refugees' extraordinary journey to Canada. I found working with them to be in line with my personal life philosophy and my values as a nurse and Canadian citizen: the belief and value of helping those who are vulnerable.

After I came home and would hear a plane flying overhead, it would bring me back to my recent experience and I would feel proud of having participated in "Operation Hope". The next time I travel, I will have a big smile at the airport because I know what goes on behind the scenes: Teams of exceptional workers are there to protect our health and prevent the spread of communicable disease. I want to say a warm thank you to my colleagues, who were generous with their time and who worked so well in our newly minted team. It is not easy to coordinate with different colleagues all the time and work all hours of the day and night, but it was worth it. This was an experience I will never forget. Shukran! 